Disclosure of Interests: Ceyhun Acarı: None declared, Elif Çomak: None declared, Şükrü Çekiç: None declared, Serkan Turkucar: None declared, Hatice Adiguzel Dundar: None declared, Sara şebnem Kılıç: None declared, Sema Akman: None declared, Erbil Unsal Grant/research support from: Novartis, AbbVie, Roche, Koçak Pharma, Speakers bureau: Novartis, AbbVie, Roche, Koçak Pharma

DOI: 10.1136/annrheumdis-2019-eular.1400

\section{AB1069 HYPERZINCAEMIA AND HYPERCALPROTECTINEMIA SYNDROME: MORE THAN JUST AUTOINFLAMMATION?}

Andrea Uva ${ }^{1,1}$, Claudia Bracaglia ${ }^{1}$, Silvia Federici ${ }^{1}$, Camilla Celani ${ }^{1}$, Manuela Pardeo ${ }^{1}$, Christoph Kessel ${ }^{2}$, Fabrizio De Benedetti ${ }^{1}$, Antonella Insalaco ${ }^{1}$. ${ }^{1}$ IRCCS Ospedale Pediatrico Bambino Gesù, Division of Rheumatology, Rome, Italy; ${ }^{2}$ University Children's Hospital, Department of Pediatric Rheumatology and Immunology, muenster, Germany

Background: Hyperzincaemia and hypercalprotectinemia $(\mathrm{HandH})$ syndrome has been described as a new rare entity characterized by recurrent infections, dermatological involvement, increased inflammatory markers, hepatosplenomegalia and anemia. Little is known about its heterogeneous presentation, pathophysiology and treatment.

Objectives: To describe three cases with $\mathrm{HandH}$ syndrome

Methods: Serum calprotectin (MRP8/14) was measured according to Buehlmann assay (ELISA) and plasmatic zinc by atomic absorption spectrometry

Results: Three patients were referred to our centre because an history characterized by recurrent episodes of skin rash, severe oral aphtosis and increased level of serum amyloid A (SAA). Patient 1 presented, since the age of ten years, with recurrent episodes of fever and rash; skin biopsy showed a picture consistent with a lymphocytic lichenoid vasculitis resembling erythema multiforme. Patient 2 presented at birth, with hemolitic anemia and thrombocytopenia. At the age of 5 she was admitted to another hospital due to EBV related hemophagocytic limphohystiocytosis (HLH). At the age of 8 , she was first seen at our center because of a persistent desquamant erythematous rash with recurrent abdominal pain and recurrent arthritis. Intestinal biopsy showed small intestine inflammation (erosions in the digiunum). Patient 3 presented with recurrent episodes of fever, rash, two episodes of transient hip synovitis and muscoloskeletal pain. A bone scintigraphy was performed resulting normal. Patients 1 and 2 suffered from recurrent infections (pneumonia, otitis, skin abscesses). Immunological studies revealed in patient 2 a reduction of memory B cells and a reduced response to Toll like receptor 9 agonist. Of note, all the patients presented in their medical history at least one episode of vasculitis: patients 1 and 3 suffered from Schonlein-Henoch's purpura at the age of 11 and 3 respectively and patient 2 had at the age of 2 years an undefined vasculitis (evaluated elsewhere). Laboratory tests showed in all patients elevated inflammatory markers, zinchemia and serum calprotectin (table)

\begin{tabular}{|l|l|l|l|}
\hline & Patient 1 & Patient 2 & Patient 3 \\
\hline $\begin{array}{l}\text { Age at 1 } \\
\text { evaluation } \\
\text { (years) }\end{array}$ & 14.3 & 7.8 & 4.9 \\
\hline Sex & F & F & M \\
\hline Clinical features & $\begin{array}{l}\text { Recurrent fever, recurrent } \\
\text { infection, vasculitis, } \\
\text { rash, musculoskeletal pain }\end{array}$ & $\begin{array}{l}\text { Hemolitic anemia, } \\
\text { thrombocytopenia, HLH, } \\
\text { vascultis, recurrent } \\
\text { infections, recurrent fever, } \\
\text { arthritis, skin rash, } \\
\text { gastrointestinal involvement }\end{array}$ & $\begin{array}{l}\text { Recurrent fever, } \\
\text { skin rash, } \\
\text { vasculitis, } \\
\text { arthritis, } \\
\text { musculoskeletal } \\
\text { pain }\end{array}$ \\
\hline SAA & $13-23$ & $27,5-76,4$ & 20 \\
\hline $\begin{array}{l}\text { Zinchemia } \\
\text { (mcg/dl) } \\
\text { (n.v. 80-125) }\end{array}$ & $132-143$ & $102-233$ & 147 \\
\hline $\begin{array}{l}\text { Serum } \\
\text { MRP8/14 } \\
\text { (ng/ml) } \\
\text { (n.v. <2900) }\end{array}$ & 22431 & 10383 & 10363 \\
\hline
\end{tabular}

Figure 1

Conclusion: We report three patients with high serum levels of calprotectinemia and zinch presenting with a clinical phenotype consistent with previously reported cases. The presence of vasculitis in all of the patients suggest that it may represent the first symptom of this condition. Vasculitis could lead to an increase of serum calprotectin already proposed as a marker of vascular impairment. Moreover, considering the immunological defect detected in one of our patient, we speculate that recurrent infections described in this syndrome may underline an immunedysregulation process in which the role of zinc metabolism needs to be assessed

Disclosure of Interests:: Andrea Uva: None declared, Claudia Bracaglia: None declared, Silvia Federici: None declared, Camilla Celani: None declared, Manuela Pardeo: None declared, christoph kessel: None declared, Fabrizio De Benedetti Grant/research support from: Abbvie, SOBI, Novimmune, Roche, Novartis, Sanofi, Pfizer, Antonella Insalaco: None declared

DOI: 10.1136/annrheumdis-2019-eular.6347

\section{AB1070 MICROVASCULAR NAILFOLD ALTERATIONS BY VIDEOCAPILLAROSCOPY IN PATIENTS WITH RHEUMATOLOGICAL SYMPTOMS WITH JUVENILE INFLAMMATORY BOWEL DISEASE}

Ana Villarreal-Trevino ${ }^{1}$, Fernando García-Rodriguez ${ }^{2}$, Nadina Rubio-Perez ${ }^{3}$, Sergio Fernández-Ortiz ${ }^{4}{ }^{1}$ Hospital Universitario "Dr. José Eleuterio González", Pediatrics, Monterrey, Mexico; ${ }^{2}$ Hospital Universitario "Dr.José Eleuterio

González", Pediatrics, Monterrey, Mexico; ${ }^{3}$ Hospital Universitario "Dr. José E. González", Pediatrics, Monterrey, Mexico; ${ }^{4}$ Hospital Zambrano Hellion TEC salud, Pediatrics, Monterrey, Mexico

Background: Juvenile Inflammatory Bowel Disease (JIBD) is a chronic relapsing inflammatory condition of the gastrointestinal system that includes Crohn's disease (CD) and Ulcerative Colitis (UC) and develops during childhood or adolescence in up to $25 \%$ of patients and affects the patients and parent $s$ quality of life. Endothelial dysfunction is considered one of the etiological factors of jIBD. Nailfold videocapillaroscopy is one of the best and safest diagnostic non-invasive imaging techniques to analyze microvascular abnormalities. Previous studies describe the involvement of the microvasculature in the pathogenesis of this diseases, suggested that chronic mesenteric vasculitis is a pathogenetic mechanism in CD. Nailfold abnormalities founded are similar to those observed in some systemic vasculitidies. Subpapillary venous plexus dropout and low vessel density were previously reported.

Objectives: In this abstract we describe nailfold videocapillaroscopy findings in patients with jIBD and their correlation with disease activity.

Methods: This is a prospective and analytical study thad recruited pediatric patients between 2 and 18 years with jIBD. A single cross-sectional 8-finger nailfold videocapillaroscopy was performed using a 200x optical probe videocapillaroscope. The images were collected, encoded and stored using the Optipi ${ }^{\circledR}$ software. Qualitative, quantitative and semiquantitative assessment for architecture were scored following the international definitions for the capillary abnormalities Blood chemistry, C-reactive Protein, erythrocyte sedimentation rate, antineutrophil cytoplasmic antibody, and calprotectin were performed. Sociodemographic data, clinical eva- luation, confirmation of IBD criteria, disease history, and activity evaluation were collected from patients clinical records. Statistics were performed using Spearman test to evaluate the correlation coefficient between the variables under study.

Results: 10 patients with jIBD were included 60\% male, 50\% Ulcerative Colitis and $50 \%$ Crohn s Disease. $20 \%$ had severe disease according the Pediatric Ulcerative Colitis Activity index, Pediatric Crohon s Disease activity index showed mild activity in just one patient. Rheumatological manifestations were found in $40 \%, 4$ had arthritis, systemic vasculitidies in 2 and $10 \%$ hematological manifestations. Abnormal endoscopy in $60 \%$ showing pancolitis. Normal microvasculature pattern were only found in 3 patients $(25 \%)$, microangiopathy was found in $75 \%$, edema of the nailfold bed was present in $n=6$ patients, a low capillary density was found in $100 \%$ of the patients with disease activity. A statistical negative correlation between the number of capillarities per millimeter and disease activity was found (coefficient $-0.936, p=0.001$ ).

Conclusion: Previous data showed that low capillary density was find in patients with jIBD, the data in this pilot study are consistent with those findings. The assessment of the microvasculature through the use of videcapillaroscopy could be useful in this diseases.

\section{REFERENCES}

1. Deban et al. Multiple Pathogenic Roles of Microvasculature in Inflammatory Bowel Disease: A Jack of All Trades. AJP June 2008, Vol. 172, No. $61457-$ 1466

Disclosure of Interests: None declared DOI: 10.1136/annrheumdis-2019-eular.7542 